\title{
MENCIPTAKAN PEMBELAJARAN YANG EFEKTIF DAN BERKUALITAS
}

\author{
Punaji Setyosari \\ Jurusan Teknologi Pendidikan, Fakultas Ilmu Pendidikan, Universitas Negeri Malang \\ J1.Semarang No.5 Malang Jawa Timur 65145 \\ E-mail: punaji-um@tep.ac.id
}

\begin{abstract}
ABSTRAK
Pembelajaran yang efektif dapat didefinisikan sebagai pembelajaran yang berhasil mencapai tujuan belajar peserta didik sebagaimana yang diharapkan oleh guru . Model pembelajaran efektif, mencakup empat hal pokok, yaitu: 1) kualitas pembelajaran, 2) tingkat pembelajaran yang memadai, 3) ganjaran dan 4) waktu. Sedangkan, kualitas pembelajaran merujuk pada aktivitas-aktivitas yang dirancang dan tindakan-tindakan yang dilakukan pembelajar dan peserta didik, termasuk di dalamnya bahan-bahan atau pengalaman belajar (kurikulum) serta media yang kita gunakan.
\end{abstract}

Kata kunci: Pembelajaran efektif,pembelajaran berkualitas dan tindak mengajar

\section{CREATING THE EFFECTIVE AND THE QUALITY OF THE LEARNING}

\begin{abstract}
Effective instruction can be defined as a successful instruction of achieving learner's learning objective as desired by teacher. The effective instructional model includes four elements, such as 1) instructional quality, 2) appropriate instructional level, 3) rewards atau incentive and 4)time. Whereas, instructional quality refers to designed activities and actions conducted by teacher and learner, including content and learning experiences (curriculum) as well as media we use.
\end{abstract}

Key words: effective instruction, instructional quality and teaching act 


\section{PENDAHULUAN}

Pembelajaran yang efektif biasanya ditandai dan diukur oleh tingkat ketercapaian tujuan oleh sebagian besar siswa. Tingkat ketercapain itu berarti pula menunjukkan bahwa sejumlah pengalaman belajar secara internal dapat diterima oleh para siswa. Pembelajaran yang efektif itu menurut Kyriacou (2009) mencakup dua hal pokok, yaitu waktu belajar aktif 'active learning time'dan kualitas pembelajaran 'quality of instruction'. Hal yang pertama berkenaan dengan jumlah waktu yang dicurahkan oleh siswa selama dalam pelajaran berlangsung. Bagaimana para siswa terlibat, engage, dalam proses pembelajaran untuk mencapai tujuan yang diharapkan. Hal yang kedua berkaitan dengan kualitas aktual belajar itu sendiri. Artinya, bagaimana proses atau interaksi pembelajaran dapat berlangsung antara guru-siswa, siswa-siswa dan siswa-sumber belajar. Dengan demikian, pembelajaran yang efektif itu tidak bisa dilepaskan dari pembelajaran yang berkualitas karena kualitas hasil belajar itu tergantung pada efektivitas pembelajaran yang terjadi atau diterjadikan di dalam proses pembelajaan itu sendiri. Lebih dari empat puluh tahun data penelitian yang telah dikumpulkan juga memperlihatkan bahwa para peserta didik yang menerima pembelajaran berkualitas tinggi menunjukkan belajar lebih sukses daripada peserta didik yang tidakmemperoleh pembelajaran yang berkualitas (Joyce, Weil, \& Calhoun, 2003).

Persoalan pendidikan, khususnya yang berkenaan dengan mutu atau kualitas pendidikan ini menyangkut terselenggaranya mutu proses dan hasil pendidikan. Mutu proses pendidikan dan pembelajaran ini perlu diselaraskan dengan standar proses yang ada. Standar proses, sebagaimana yang dinyatakan dalam pasal (1) Peraturan Pemerintah
Nomor 19 tahun 2005 tentang Standar Nasional Pendidikan salah satu standar yang harus dikembangkan adalah standar proses. Standar proses adalah standar nasional pendidikan yang berkaitan dengan pelaksanaan pembelajaran pada satuan pendidikan untuk mencapai kompetensi lulusan.Standar proses berisi kriteria minimal proses pembelajaran pada satuan pendidikan dasar dan menengah di seluruh wilayah hukum Negara Kesatuan Republik Indonesia. Standar proses ini berlaku untuk jenjang pendidikan dasar dan menengah pada jalur formal, baik pada sistem paket maupun pada sistem kredit semester. Standar proses meliputi perencanaan proses pembelajaran, pelaksanaan proses pembelajaran, penilaian hasil pembelajaran, dan pengawasan proses pembelajaran untuk terlaksananya proses pembelajaran yang efektif dan efisien (Permendiknas, nomor 41 tahun 2007).

\section{PEMBAHASAN}

Tugas Guru: Menumbuhkan dan Memfasilitasi Proses Pembelajaran

Pembelajaran sebagai upaya memfasilitasi atau mempermudah peserta didik dalam belajar. Smith \& Ragan (2003) menyatakan bahwa pembelajaran merupakan penyampaian informasi dan aktivitas-aktivitas yang memudahkan atau memfasilitasi peserta didik untuk pencapaian tujuan khusus belajar yang diharapkan. Dan, dalam proses pembelajaran tersebut, belajar merupakan pusat atau sentralnya pengalaman dalam kelas bagi peserta didik dan guru baik di jenjang pendidikan dasar maupun menengah (Hewitt, 2008). Agar terjadi proses pembelajaran yang efektif, kita perlu memusatkan perhatian padapeserta didik. Pandangan ini sejalan dengan Hiltz (dalam 
Setyosari, 2009) yang mengungkapkan bahwa pembelajaran berpusat pada peserta didik (learnercentered) bukan berpusat pada guru (teachercentered) dan pengetahuan dipandang sebagai suatu konstruk sosial (a social construct), yang dapat dilakukan melalui interaksi sebaya (peer interaction), menilai kegiatan belajar dan kerja sama.

Kita, para guru (pembelajar) mengemban tugas utama yaitu mendidik dan mengajar. Tugas utama atau tugas pokok ini menurut Gagne (1985) mencakup merancang (design), melaksanakan (execute) dan menilai (evaluate). Tugas merancang dilakukan sebelum pelaksanaan kegiatan di dalam kelas, yaitu merencanakan seluruh aktivitas yang dilakukan agar terjadinya proses belajar bagi peserta didik. Setelah merancang kegiatan, selanjutnya guru melaksanakan seluruh aktivitas-aktivitas sesuai dengan rancangan mulai dari kegiatan awal (pendahuluan), kegiatan inti atau pokok atau disebut juga kegiatan pengembangan, dan diakhiri dengan kegiatan menutup pelajaran. Dan, sebagai akhir tugas guru adalah menilai kegiatan pembelajaran tersebut baik proses maupun hasilnya. Kegiatankegiatan yang dilakukan oleh guru inilah diidentifikasi sebagai kegiatan yang sesuai dengan standar proses.

Pembelajaran hendaknya memfokuskan pada proses mendidik, yang menjadi tugas utama pembelajar (Setyosari, 2009). Ketiga tugas utama sebagaimana yang telah dikemukakan di atas, sejalan dengan salah satu tugas guru dalam upaya mengembangkan standar nasional pendidikan, yaitu standar proses. Merancang proses pembelajaran yang akan dilaksanakan di kelas perlu dilakukan secara cermat. Merancang pembelajaran merujuk pada suatu proses secara sistematis untuk menjabarkan prinsip-prinsip belajar dan pembelajaran ke dalam suatu perencanaan untuk menyajikan materi pembeajaran dan aktivitasaktivitas pembelajaran (Smith \& Ragan, 1993).

Tugas kedua adalah melaksanakan pendidikan dan pembelajaran. Tugas mendidik ini sangat berkaitan dengan mengembangtumbuhkan peserta didik menjadi manusia dewasa. Manusia dewasa itu ditandai oleh adanya kedewasaan berpikir (intelektual), mengelola perasaan diri (emosi), berkembangnya kemampuan membedakan tindakan baik dan jelek/buruk (moral/etika), menilai hal-hal yang indah dan tidak (estetika), bekerja sama dengan orang lain (sosial) dan aspek-aspek lain. Tugas mengajar sangat berkaitan dengan tugastugas mengembangkan tiga aspek utama, yang oleh Bloom dkk.diidentifikasi sebagai aspek atau matra kognitif, psikomotorik dan afektif. Ketiga aspek ini merupakan dimensi olah pikir, dimensi olah raga dan dimensi olah rasa (Setyosari, 2009). Secara terintegrasi ketiga aspek ini perlu dibelajarkan untuk dimiliki oleh peserta didik. Tugas kedua ini terwujud dalam bentuk, yang oleh Gagne (1985) disebut sebagai peristiwa pembelajaran, "the events of instructions." Peristiwa pembelajaran ini mencakup: 1) menarik perhatian (gaining attention), 2) menyampaikan tujuan khusus pembelajaran (informaing instructional objectives), 3) membangkitkan hal-hal yang telah dimiliki oleh peserta didik/pebelajar atau pemelajar (stimulating recall of prerequisite learning), 4) menyajikan bahan atau materi pembelajaran (presenting stimulus materials), 5) memberikan latihan terbimbing (providing learning guidance), 6) menampilkan unjuk kerja (eliciting performance), 7) memberikan balikan (providing feedback), 8) menilai unjuk kerja (assessing performance), dan 9) meningkatkan 
retensi dan transfer (enhancing retention and transfer). Berkaitan dengan tugas kedua ini, ada tiga kegiatan yang perlu dilakukan (menurut Permendiknas, 2007) yaitu: 1) kegiatan pendahuluan; 2) kegiatan inti, yang mencakup (a) eksplorasi, (b) elaborasi dan (c) konfimasi; dan 3) kegiatan penutup. Kegiatan pembelajaran ini menurut Smith \& Ragan (1993) mencakup empat peristiwa, yang disebut, “ expanded instructional events." Peristiwa pembelajaan tersebut meliputi: 1) pendahuluan (introduction), 2) pokok (body), 3) kesimpulan (conclusion) dan 4) penilaian (assessment). Ketiga langkah proses pembelajaran tersebut dapat diperiksa pada Table 1 .

Dalam kaitan dengan tugas ketiga, yaitu menilai keseluruhan aktivitas yang telah dirancang dan dilakukan yang dalam hal ini berupa program pembelajaran. Penilaian ini mencakup penilaian proses dan hasil, yaitu mulai dari kegiatan perencanaan, proses kegiatan pembelajaran hingga hasil yang ditentukan.

\section{Pembelajaran Efektif dan Berkualitas}

Sebelum berbicara mengenai kualitas pembelajaran lebih jauh, ada dua pertanyaan yang muncul, yaitu: Apakah yang dimaksud pembelajaran berkualitas itu? dan Apakah yang dimaksud pembelajaran efektif? Permasalahan yang pertama telah lama menjadi pusat perhatian banyak pihak, bahkan sejak awal kemerdekaan hingga sekarang. Masalah kualitas ini justru seperti bola salju, yang semakin lama semakin menjadi besar, dan apabila tidak kita cari solusinya masalah kualitas itu akan menjadi seperti benang kusut, yang sulit dicari mana ujung dan pangkalnya. Masalah kedua, terkait dengan seberapa jauh capaian atau hasil yang dicapai melalui proses pembelajaran yang kita lakukan di kelas.

\section{Karakteristik Pembelajaran yang Efektif}

Pembelajaran yang efektif, sesungguhnya bukan sesuatu yang mudah dan sederhana. Pembelajaran yang efektif, bukan hanya masalah tercapainya seluruh tujuan khusus pembelajaran. Banyak aspek yang terlibat di dalamnya. Kita nampaknya sepaham bahwa sebagian besar kajian atau literature menyatakan pembelajaran yang efektif itu merupakan suatu proses yang benar-benar kompleks (MacGregor, 2007).Pembelajaran efektif

Tabel 1: Tahap-tahap Proses Pembelajaran

\begin{tabular}{|c|c|c|}
\hline $\begin{array}{l}\text { Peristiwa Pembelajaran } \\
\text { (Gagne, et.al., 1992) }\end{array}$ & $\begin{array}{l}\text { Kegiatan Pembelajaran } \\
\text { (Permendiknas 2007) }\end{array}$ & $\begin{array}{l}\text { Peristiwa Pembelajaran } \\
\text { (Smith \& Ragan, 1993) }\end{array}$ \\
\hline $\begin{array}{l}\text { 1) menarik perhatian } \\
\text { 2) menyampaikan tujuan } \\
\text { khusus pembelajaran } \\
\text { 3) membangkitkan hal-hal } \\
\text { yang telah dimiliki oleh } \\
\text { peserta didik }\end{array}$ & 1) kegiatan pendahuluan; & 1) pendahuluan (introduction), \\
\hline $\begin{array}{l}\text { 4) menyajikan bahan atau } \\
\text { materi pembelajaran } \\
\text { 5) memberikan latihan } \\
\text { terbimbing } \\
\text { 6) menampilkan unjuk kerja }\end{array}$ & $\begin{array}{l}\text { 2) kegiatan inti, yang mencakup } \\
\text { a) eksplorasi, } \\
\text { b) elaborasi dan } \\
\text { c) konfimasi; dan }\end{array}$ & 2) pokok (body), \\
\hline $\begin{array}{l}\text { 7) memberikan balikan } \\
\text { 8) menilai unjuk kerja } \\
\text { 9) meningkatkan retensi } \\
\text { dan transfer }\end{array}$ & 3) kegiatan penutup. & $\begin{array}{l}\text { 3) kesimpulan (conclusion) } \\
\text { 4) penilaian (assessment). }\end{array}$ \\
\hline
\end{tabular}


sesungguhnya terkait dengan aspek-aspek pembelajaran dan seberapa kemampuan guru menentukan suatu pengalaman belajar yang mengarah pada pencapaian hasil (belajar) yang diharapkan. Agar supaya hal ini bisa terwujud, maka setiap peserta didik harus dilibatkan dalam aktivitas pembelajaran. Kyriacou (2009) menyatakan bahwa pembelajaran yang efektif dapat didefinisikan sebagai pembelajaran yang berhasil mencapai tujuan belajar peserta didik sebagaimana yang diharapkan oleh guru. Sedikitnya ada dua unsur pokok dalam pembelajaran yang efektif, yaitu 1) guru harus memiliki suatu gagasan jelas tentang tujuan belajar yang diharapkan dan 2) pengalaman belajar yang direncanakan dan disampaikan dapat tercapai.

Pembelajaran yang efektif ini juga sangatterkait dengan guru yang efektif. Good and Brophy (dalam MacGregor, 2007) menjelaskan bahwa guru yang efektif ini adalah guru yang: 1) guru yang menggunaian waktu pembelajaran secara maksimal, 2) menyajikan bahan atau materi pembelajaran dengan cara tertentu sehingga memenuhi kebutuhan peserta didik, 3) memantau program dan kemajuan, 4) merancang kesempatan belajar bagi peserta didik untuk menerapkan pengalaman belajarnya, 5) bersedia mengulang kembali jika diperlukan dan 6) mematok harapan tinggi, tetapi tujuan tersebut realistik.

Slavin (1994) menyusun suatu model pembelajaran efektif, didasarkan atas hasil kerja Carroll, dan mengidentifikasi unsur-unsur atau elemen-elemen pembelajaran sebagai berikut. Unsur-unsur model mencakup empat hal pokok, yaitu: 1) kualitas pembelajaran, 2) tingkat pembelajaran yang memadai, 3) ganjaran dan 4) waktu. Kualitas pembelajaran berkenaan dengan seberapa tinggi tingkat informasi atau keterampilan yang disajikan kepada para peserta didik itu mudah dipelajari mereka. Kualitas pembelajaran itu pada umumnya berupa hasil yang berkualitas berkenaan dengan pengalaman belajar atau kurikulum dan pelajaran itu. Tingkat pembelajaran yang memadai merujuk pada seberapa jauh guru yakin bahwa para peserta didik siap belajar sesuatu hal yang baru. Artinya, mereka memiliki keterampilan dan pengetahuan yang diperlukan untuk mempelajari hal baru tersebut, yang sebelumnya belum pernah dipelajarinya. Dengan ungkapan lain, tingkat pembelajaran itu memadai jikalau suatu pelajaran tidak terlalu sulit dan juga tidak terlalu mudah bagi peserta didik. Ganjaran menyangkut hal yang berkenaan bahwa guru yakin para peserta didik termotivasi untuk mengerjakan tugas-tugas pembelajaran dan ingin belajar tentang hal yang telah disampaikan, tentu saja setelah mendapatkan penguatan atau ganjaran yang diberikan oleh guru. Terakhir, berkaitan dengan waktu yang dalam hal ini seberapa cukup waktu yang digunakan untuk belajar peserta didik untuk mempelajari hal-hal yang telah disampaikan oleh guru.

Keempat unsur model di atas, yaitu:kualitas (quality), kesesuaian (appropriate), insentif atau ganjaran (incentive) dan waktu yang digunakan (time). Empat unsur itu KKIW atau yang oleh Slavin disebut dengan model QAIT (Quality, Appropriateness, Incentive, Time) ., yang kesemuanya harus selaras bagi terjadinya pembelajaran yang efektif. Kita menyadari, pembelajaran yang efektif bukan hanya pembelajaran yang berlangsung baik, tetapi pembelajaran yang efektif itu melibatkan banyak unsur yang saling berkaitan . Betapa pun tingginya kualitas pembelajaran, peserta didik tidak akan 
belajar jika mereka tidak memiliki pengetahuan dan keterampilan sebelumnya yang diperlukan, jika meereka tidak termotivasi, jika mereka memiliki waktu kurang yang diperlukan untuk belajar. Sebaliknya, jika kualitas pembelajaran rendah maka hal tersebut akan memberikan dampak kecil bagi belajarnya peserta didik, walaupun mereka para peserta didik memiliki motivasi dan waktu yang cukup untuk belajar. Perlu kita ketahui bahwa setiap elemen atau unsur dalam model tersebut saling terkait seperti jalinan yang membentuk suatu rantai sebagaimana diperlihatkan pada Gambar 1.

\section{Variabel konteks}

Variabel konteks merujuk pada karakterikstik atau ciri-ciri konteks kegiatan belajar, yang biasanya berdasarkan kelas, yang mungkin memiliki dampak keberhasilan kegiatan belajar. Variabel ini berkaitan dengan latar belakang guru, peserta didik atau siswa, kelas yang ada, bidang studi atau mata pelajaran, sekolah, latar atau lingkungan dan situasi masyarakat dimana pembelajaran terjadi dan diterjadikan serta ketersediaan waktu yang dapat dimanfaatkan secara efektif. Faktor-faktor yang ada dalam lingkungan belajar memberikan pengaruh terhadap hasil belajar peserta didik.

\section{Variable proses}

Variabel proses merujuk pada apa ya ng sesungguhnya terjadi atau berlangsung dalam kelas, berkenaan dengan persepsi, strategi dan tindakan guru dan peserta didik, dan karakateristik tugastugas dan aktivitas-aktivitas belajar tersebut dan bagaimana hubungannya satu d engan yang lain. Faktor-faktor tersebut meliputi antusiasme guru,

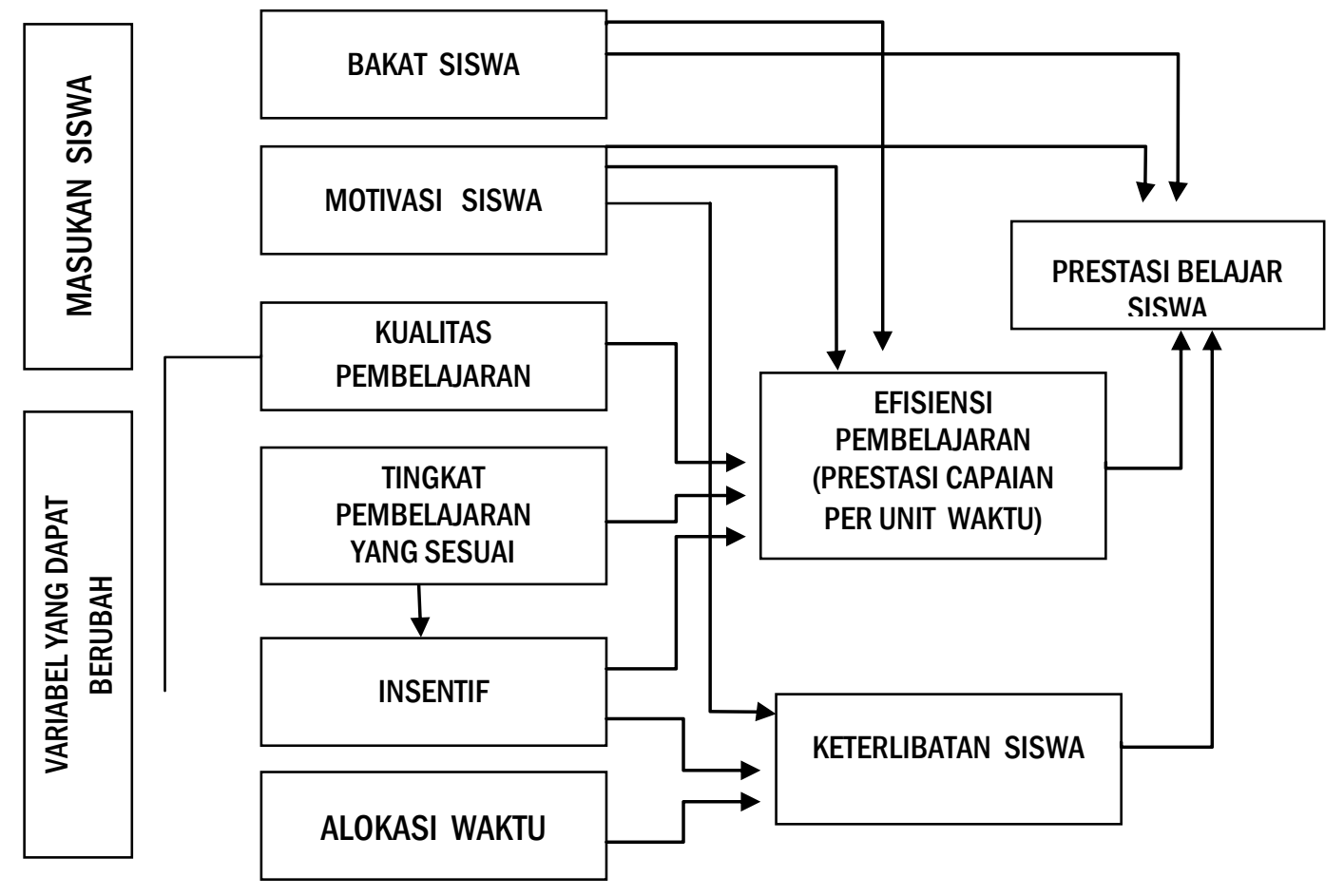

Gambar 1: Model QAIT

(Sumber: Slavin (1994). A Model of Effective Instruction. The Office of Educational Research and Improvement, U.S. Department of Education) 
kejelasan uraian guru, penggunaan pertanyaan, penggunaan penghargaan dan kritik, strategi pengelolaan, teknik pendisiplinan, iklim kelas atau pembelajaran, organisasi pelajaran, kesesuaian tugas-tugas belajar, jenis balikan yang diterima peserta didik, keterlibatan peserta didik dalam belajar, interaksi peserta didik dan guru dan strategi belajar yang digunakan oleh peserta didik.Berkenaan dengan pembelajaran yang efektif tersebut ada tiga faktor atau variabel yang terkait. Ketiga faktor tersebut menurut Kyriacou (2009) diperlihatkan pada Gambar 2.

\section{Variabel Hasil}

Variabel hasil berkenaan dengan capaian akhir setelah melalui proses pembelajaran dalam kurun waktu tertentu. Hasil belajar ditandai dengan tingkat ketercapaian siswa atau peserta didik terkait dengan hal yang dipelajarinya. Capaian atau hasil belajar ini mencakup domain kognitif (kemampuan untuk mengingat, memahami, menerapkan, menganalisis, dan menciptakan), afektif atau sikap (kesadaran untuk menerima, menghargai, bertindak sesuai kaidah atau aturan dan sebagainya) dan psikomotorik (bertindak sesuai dengan atau melakukan aktivitas atau gerakan otot yang didasari intelektual dan perasaan atau emosi).

\section{Variabel Ekstra}

Faktor lain yang bersifat kontigensi; misalnya peristiwa yang terjadi pada saat pelajaran berlangsung. Hal-hal yang berada di luar atau di sekitar siswa (peserta didik) pada saat siswa belajar dapat mempengaruhi proses belajar, yang pada gilirannya juga berpengaruh pada tercapainya tujuan belajar. Faktor-faktor yang bersifat incidental atau

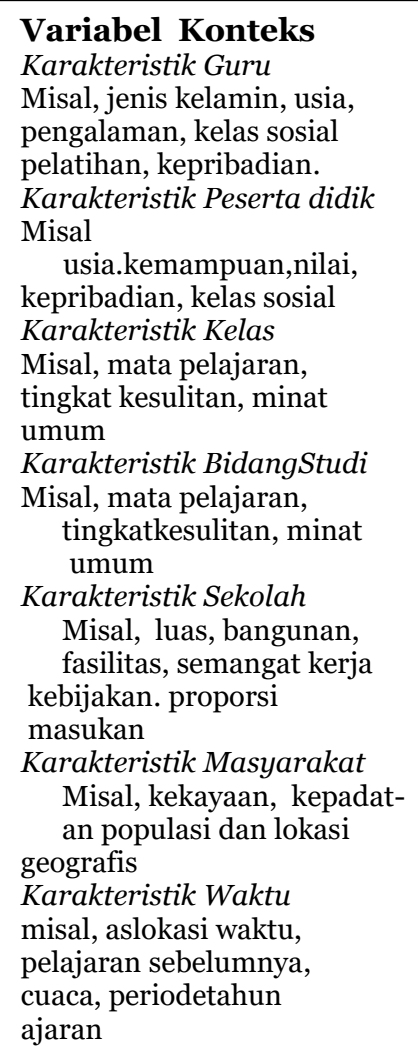

\section{Variabel Hasil}

Hasil pendidikan kognitif, afektif jangka panjang/pendek. Misal, perubahan sikap peserta didik terhadap sekolah dan mata pelajaran; hasil didasarkan pada capaian standar, meningkatnya tingkat konsep diri, keberhasilan ujian nasional dan kemandirian peserat didik semakin besar.

Gambar 2: Kerangka Dasar Berpikir tentang Pengajaran yang Efektif 
sementara ini menjadi faktor intervensi bagi keberlangsungan dan kelancaran belajar siswa.

\section{Variabel sistem pendukung}

Sinergi diantara komponen pembelajaran untuk mencapai tujuan khusus (standar/tujuan, isi, strategi, media dan sumber belajar serta evaluasi) sangat diperlukan. Ketersediaan media, teknologi, sumber belajar dan lingkungan atau latar belajar yang memadai sangat membantu siswa dalam belajar. Lingkungan belajar menurut pandangan atau teori kognitif dan konstruktivistik yang telah menempatkan siswa sebagai "a constructor," bukan sebagai "a receiver atau recipient," pengetahuan. Penyediaan lingkungan belajar yang lebih imersif dan teknologi pembelajaran sebagai sarana kognitif membantu guru dalam merancang dan menciptakan yang selanjutnya dapat digunakan untuk membimbing siswa, yang oleh Molenda dan Januszewski (2008) ditegaskan untuk, "to make learning opportunities, and to assist learners in finding answers to their questions."

\section{Pembelajaran Berkualitas}

Berbicara masalah kualitas tentu sangat terkait dengan seberapa besar layanan yang kita berikan kepada peserta didik. Kita tidak bisa menuntut banyak kepada peserta didik, jika layanan yang kita berikan sangat terbatas. Artinya, layanan belajar yang kita berikan seharusnya memberikan peluang besar bagi perkembangan keseluruhan aspek peserta didik. Kualitas pembelajaran merujuk pada aktivitas-aktivitas yang kita rancang dan tindakan-tindakan yang kita lakukan dan dilakukan oleh peserta didik, termasuk di dalamnya bahanbahan atau pengalaman belajar (kurikulum) serta media yang kita gunakan. Jika pembelajaran yang kita lakukan berkualitas, maka bahan atau informasi yang disajikan kepada peserta didik mudah dipahami, mudah diingat dan diaplikasikan oleh peserta didik. Hal yang terpenting tentang kualitas pembelajaran adalahseberapa tinggi tingkat atau derajad dimana pelajaran mudah bagi peserta didik (Slavin, 1994).

Kita tahu dan sadar bahwa peserta didik sesungguhnya telah memiliki potensi dan kapabilitas yang dibawa (internal capabilities). Sehubungan dengan hal tersebut Hewitt (2008) menyatakan, "Pupils have their own views on how they learn. In many classes group work is seen as a very effective classroom arrangement for promoting dialogue and learning." Artinya, peserta didik telah memiliki pandangan sendiri terkait dengan belajarnya. Dalam berbagai pembelajaran di kelas kerja kelompok dipandang sebagai penataan kelas yang paling efektif untuk meningkatkan dialog dan belajar. Kita, sebagai guru (pembelajar) perlu memfasilitasi dan mempermudah bagi terjadinya belajar peserta didik, sehingga mereka (para peserta didik) mampu berkembang lebih jauh. Dary, et.al. (2010) menyatakan, “ High quality service-learning practice does not happen by accidentor in isolation. It requires a systems approach to the process, grounding implementation solidly in the $k-12$ service-learning standards for quality practice. High quality service-learning engages students who use the concepts and skills they learn inschool." Layanan belajar yang berkualitas itu tidak terjadi begitu saja. Layanan belajar yang berkualitas ini menuntut suatu pendekatan sistem terhadap proses, yang mendasarkan pada penerapan secara solid sesuai dengan standar layanan belajar mulai dari pendidikan anak usia dini hingga di sekolah menengah (yang di USA di sebut K-12, 
kindergarten hingga kelas 12). Layanan belajar yang berkualitas tersebut melibatkan peserta didik mulai dari belajar menggunaan konsep-konsep dan keterampilan-keterampilan yang mereka pelajari di sekolah.

Layanan belajar sangat terkait dengan tindak mengajar guru. Tindakan guru menyangkut apa yang dikatakan, apa yang dilakukan, menyiapkan materi pelajaran, menyampaikan materi kepada peserta didik, berinteraksi dengan peserta didik dan menilai hasil kerja peserta didik. Tentu saja, hal tersebut belumlah cukup karena guru juga perlu melihat proses pembelajaran yang terjadi sebagai wujud layanan belajar bagi peserta didik. Keputusan-keputusan yang dibuat oleh guru selalu didasarkan pada tindakan-tindakannya di dalam kelas terutama berkenaan dengan apa yang dicapai oleh peserta didiknya. Dalam membuat keputusan tentang kualitas pembelajaran sangat penting mempertimbangkan tindak mengajar tersebut di atas ( Lawson, Askell-Williams, H., \& Murray-Harvey, dalam Saha \&Dworkin, 2009).Kerr (dalam Saha \&Dworkin, 2009) menyatakan bahwa suatu tindak mengajar guru itu mencakup tiga tindakan secara berurutan, yaitu: 1) membuat suatu pilihan tentang suatu belajar yang dapat mendorong peserta didik, 2) merancang suatu perencanaan untuk mendorong belajar tersebut, dan 3) melaksanakan berdasarkan perencanaan tersebut.

Berkenaan dengan kualitas pembelajaran, ada 6 hal esensial praktik yang menandai kualitas pembelajaran dan belajar. Keenam hal esensial dalam praktik pembelajaran sebagai berikut, yaitu: 1) guru merancang secara efektif pembelajaran yang berpusat pada standar, 2) guru menyampaikan pembelajaran berkualitas tinggi, berpusat pada peserta didik, 3) guru meningkatkan keterlibatan peserta didik , 4) guru menggunakan penilaian untuk belajar peserta didik, 5) guru menggunakan strategi pengelolaan perilaku secara positif dan 6) adanya kejelasan belajar peserta didik (MacGregor, 2007).

Apa ciri-ciri pendidikan yang berkualitas itu? Ada beberapa dimensi yang menandai pendidikan berkualitas. Dimensi-dimensi tersebut (Unicef, 2000) meliputi sebagai berikut.

1) Para peserta didik dalam keadaan sehat, terpenuhi gisi dan siap untuk terlibat dalam proses belajar, ada dukungan keluarga dan masyarakat dalam belajar;

2) Lingkungan yang sehat, aman, nyaman, terlidungi dan memperhatikan gender serta menyediakan sumber-sumber dan fasilitas yang memadai;

3) Isi atau bahan yang termuat dalam kurikulum relevan untuk mendukung pemerolehan keterampilan dasar, khususnya terkait bidang kemahirwacanaan, berhitung dan kecakapan hidup serta pengetahuan yang terkait misalnya masalah gender, kesehatan, nutrisi, pencegahan HIV/AIDS dan perdamaian;

4) Proses pembelajaran yang dilakukan oleh guru yang terlatih dengan menggunakan pendekatan yang berpusat pada anak ( child-centred teaching approaches) dalam kelas dan sekolah yang dikelola dengan baik serta asesmen tepat untuk memfasilitasi belajar dan mengurangi disparitas;

5) Hasil belajar yang mencakup pengetahuan, keterampilan dan sikap yang berkaitan dengan tujuan (standar ) pendidikan 
nasional sehingga mereka mampu berpartisipasi dalam kehidupan masyarakat.

Berdasarkan paparan di atas, secara singkat dapat kita ungkapkan bahwa pembelajaran yang efektif dan berkualitas itu, yaitu pembelajaran yang dilaksanakan dengan memperhatikan seluruh masukan (input) mulai dari perencanaan sesuai dengan variabel konteks, variabel proses (termasuk faktor-faktor yang berubah) dan hasilnya yang ditandai pula oleh eserta didik yang sehat, lingkungan sehat, isi atau kurikulum sesuai, proses pembelajaran berfokus pada peserta didik sehingga tercapai hasil pengetahuan, keterampilan dan sikap sesuai standar yang ditetapkan.

\section{KESIMPULAN}

Ada tiga tugas utama atau tugas pokok guru, yaitu mencakup merancang (design), melaksanakan (execute) dan menilai (evaluate), dan menurut Permendiknas 41/2007 ditambah lagi dengan tugas pengawasan. Tugas utama tersebut terarah untuk mendukung pencapaian kualitas pendidikan, atau pembelajaran secara khusus. Untuk mewujudkan standar proses, ditentukan adanya tiga tahap pokok kegiatan, yang mencakup kegiatan pendahuluan, pokok dan penutup.

Parameter keberhasilan guru dalam memenuhi standar proses sangat tergantung pada tingkat keterlaksanaan seluruh proses kegiatan atau aktivitas yang dirancang oleh guru di dalam kelas. Indikator keberhasilan dan keefektifan pembelajaran juga ditentukan dan bahkan dipengaruhi oleh variabel-variabel lain, konteks, proses, ekstra dan system pendukung yang ada.

Springer Science+Business Media, LLC, p. 243257.
Kualitas hasil pembelajaran atau pendidikan ditandai oleh adanya siswa yang sehat, lingkungan sehat, nyaman dan aman, isi atau kurikulum yang relevan, pembelajaran berpusat pada peserta didik dan hasil belajar secara terintegrasi mecakup pengetahuan, keterampilan dan sikap.

\section{DAFTAR PUSTAKA}

Dary, T., Prueter, B., Grinde, J., Grobschmidt, R., Evers, T. (2010). High Quality Instruction That Transforms: A Guide to Implementing Quality Academic Service-Learning. Wisconsin: Department of Public Instruction.

Gagne, R.M. (1985).The Condition of Learning. New York: Holt, Rinehart And Winstone

Hewitt, D. (2008). Undertanding Effective Learning. Strategies for The Classroom. NY: McGraw-Hill Education, Open University Press.

Huitt, W., Monetti, D., \& Hummel, J. (2009). Designing Direct Instruction. Pre-publication version of chapter published in C. Reigeluth and A. Carr-Chellman, Instructional-Design Theories dnd Models: Volume III, Building A Common Knowledgebase[73-97]. Mahwah, NJ: Lawrence Erlbaum Associates.

Joyce, B., \& Weil, M., \& Calhoun, E. (2003). Models of Teaching (7th ed.). Boston: Allyn \& Bacon.

Kyriacou, C. (2009) Effective Teaching in Schools: Theory and Practice.Third Edition. Delta Place, Cheltenham, UK: Nelson Thornes Ltd

Molenda, M., \& Januszewski, A. (2008). Educational Technology. A Dfinition with Commentary. NY: Lawrence Erlbaum Associates.

Michael J. Lawson, M.J., Helen Askell-Williams, H., \& Murray-Harvey, R. (2009). Dimensions of Quality in Teacher Knowledge. In Lawrence J. Saha \& A. Gary

Dworkin (Eds). International Handbook of Research on Teachers and Teaching. NY:

Peraturan Pemerintah Republik Indonesia Nomor 19 Tahun 2005. Standar Nasional Pendidikan. Jakarta: Kemendikbud. 
PeraturanMenteri Pendidikan NasionalRepublik IndonesiaNomor 41 Tahun 2007.

Standar Prosesuntuk Satuan Pendidikan Dasardan Menengah. Jakarta:Kemendikbud

Setyosari, P. (2009). Pembelajaran Kolaborasi: Mengembangkan Keterampilan Sosial,Rasa Saling Menghargai dan Tanggung Jawab. Pidato Pengukuhan Guru Besar dalam Bidang Ilmu Teknologi Pembelajaran pada Fakultas Ilmu Pendidikan Universitas Negeri Malang Disampaikan pada Sidang Terbuka Senat Universitas Negeri Malang.
Slavin, R. (1994). A Model of Effective Instruction. The Office of Educational

Research and Improvement, U.S. Department of Education. No. OERI-R-117-R-90002

Smith, P.L., \& Ragan, T.J. (1993).Instructional Design. NY: Macmillan Publishing Company.

UNICEF. (2000).Defining Quality in Education. A paper presented by UNICEF at the meeting of The International Working Group on Education Florence, Italy. June 2000 